Open Access

\title{
Exploring EFL learners' inferential reading comprehension skills through a flipped classroom
}

\author{
Fatemeh Samiei and Saman Ebadi ${ }^{*}$
}

\author{
*Correspondence: samanebadi@ \\ gmail.com \\ Faculty of Humanities, Razi \\ University, Kermanshah, Iran
}

\begin{abstract}
This study presents the results of a mixed-methods approach in finding the effects of the WebQuest-based flipped classroom on the EFL learners' inferential reading comprehension skills. A group of EFL learners attending an IELTS course participated in the study. T-test and one-way repeated measures ANOVA were used to analyze the quantitative data. The results showed that the WebQuest-based flipped classroom effectively developed the learners' inferential reading comprehension skills, and its long-term effect was also confirmed through the delayed post-test scores. The participants' attitudes towards the WebQuest-based flipped classroom effects were also explored by conducting semi-structured interviews analyzed by utilizing thematic analysis through which the participants' perspectives were coded and categorized. The findings revealed the EFL learners' mainly positive attitudes towards the effectiveness of this innovative approach in developing their inferential reading comprehension skills. The pedagogical implications of using WebQuest-based flipped instruction as an efficient and effective alternative to traditional classroom practice are discussed.
\end{abstract}

Keywords: Inferential skills, WebQuest, Flipped classroom, Reading comprehension

\section{Introduction}

Kintsch (2012) describes reading comprehension as the process of acquiring and constructing meaning from written text. Effective readers need to implement practices such as relating their background knowledge to the text, summarizing details, drawing conclusions, and raising questions to comprehend the text (Kirmizi, 2010). Reading comprehension is a dynamic process between the recognition of written symbols and the understanding of the context behind the symbols, and the discovery of the link between words and concepts. It is regarded as a significant and challenging skill in the language learning process in international tests such as IELTS and TOEFL (Paris \& Hamilton, 2009; Pellegrino \& Hilton, 2012; Hung, 2015). Generally, reading comprehension involves two fundamental processes: First, it deals with comprehension related to the translation of the text into linguistic concepts, and second, it combines them

(c) The Author(s). 2021 Open Access This article is licensed under a Creative Commons Attribution 4.0 International License, which permits use, sharing, adaptation, distribution and reproduction in any medium or format, as long as you give appropriate credit to the original author(s) and the source, provide a link to the Creative Commons licence, and indicate if changes were made. The images or other third party material in this article are included in the article's Creative Commons licence, unless indicated otherwise in a credit line to the material. If material is not included in the article's Creative Commons licence and your intended use is not permitted by statutory regulation or exceeds the permitted use, you will need to obtain permission directly from the copyright holder. To view a copy of this licence, visit http://creativecommons.org/licenses/by/4.0/. 
into meaningful forms at the higher level (Kendeou, van den Broek, Helder, \& Karlsson, 2014).

Inferential reading is the ability to realize the hidden concepts and the unstated relationship between the lines in a text. This ability is commonly evaluated through items that ask about the main topic, cause-effect relations, and conclusion making in standardized reading tests (Hamouda \& Tarlochan, 2015). Jang (2009) states that "items measuring the inferencing skill proved to be more cognitively demanding and required test-takers to use multiple skills simultaneously" (p. 225). These skills include the ability to comprehend difficult vocabulary and structures and synthesize background knowledge to create meaning (Graesser, Singer, \& Trabasso, 1994; McKoon \& Ratcliff, 1992; Van Den Broek, Young, Tzeng, \& Linderholm, 1999; Van Dijk \& Kintsch, 1983). Jang indicates that items targeting inferencing skills provide significant information about learners' overall reading comprehension skills.

Scheiter, Gerjets, Vollmann, and Catrambone (2009) indicated that students with higher levels of background knowledge use deeper processing strategies in reading comprehension because the background knowledge helps them with information selection and, consequently, reduces their cognitive load during reading comprehension. Traditionally, students who learn reading comprehension skills in teacher-dominated classrooms might not have enough time to activate their skills and build schemes for active participation in class discussions. Today, to fill this gap of inadequate processing time in reading comprehension, an increasing number of educational institutions have started using the flipped model in their courses. According to Boucher, Robertson, Wainner, and Sanders (2013), several potential benefits are related to using time differently in flipped learning, including having more time for interaction and deeply and more active learning opportunities for students.

Despite the flipped classroom's numerous advantages reported in the literature, this approach proved problematic in some aspects. Some studies doubted the flipped classroom's effectiveness over the traditional classroom (McClelland, 2013; Velegol, Zappe, \& Mahoney, 2015).

Howitt and Pegrum (2015) point out that the flipped classroom creates a heavy workload for teachers and students. Teachers might find it difficult to convert a traditional course into a flipped course. On the other hand, students might not be interested in ready-made materials and invest less effort in pre-class preparation, which results in their poor performance in-class activities and dissatisfaction with the flipped approach (Karabulut-Ilgu, Jaramillo Cherrez, \& Jahren, 2018). To alleviate these drawbacks of flipped learning, WebQuests, regarded as an inquiry-oriented activity (Dodge, 2001), are used in the flipped model as a form of active learning strategy to deliver the content systematically over the web digitally. Dodge (2001) pioneered WebQuest, a framework for teachers to structure student-centered learning using pre-specified assignments and pre-selected Internet sources to enable learners to locate quality information and find the most relevant pieces of the multitude of information on the Internet (Dodge, 1995).

The flipped instructional model in English classes develops students' academic performance in general (Hung, 2015). However, as a relatively recent phenomenon, little systematic research appears to be conducted to evaluate the flipped model's effects (Goodwin \& Miller, 2013), especially on reading comprehension skills in the EFL context. 
A number of studies (Alshumaimeri \& Almasri, 2012; Arsanjani \& Faghih, 2015; Irzawati \& Asiah, 2013; Tuan, 2011) investigated the effects of WebQuest-based flipped classroom on learners' reading comprehension and identifying the main topics of texts (Tsai, 2006). Although these studies found WebQuest useful in enhancing students' reading comprehension in the EFL context, they did not systematically investigate their participants' inferential reading skill, which is a crucial step in the development of reading comprehension. This study is intended to investigate the development of EFL learners' inferential reading skills in a flipped classroom using WebQuests. It also explores the learners' perceptions of the degree of engagement, satisfaction, and consequences of learning in a flipped classroom. Specifically, the research questions related to this research are as follows:

1. What are the effects of WebQuest-based flipped classroom on EFL learners' inferential reading skills?

2. What are the participants' attitudes and perceptions towards their inferential reading skills in the WebQuest-based flipped classroom?

\section{Review of related literature}

\section{Collaborative active learning}

One of the main objectives of teaching English is to achieve a practical command over the language, so teachers attempt to provide the learning situation to become independent and responsible for their learning (Shea et al., 2012). In recent years, active learning methods have positively impacted the learning process (Baepler, Walker, \& Driessen, 2014). Collaborative learning (CL), among other methods, is considered as one of the most effective approaches of active learning (Prince, 2004), which engages learners in the learning process through active participation in the learning environment (Lee, 2014). Limited time is a major barrier to introducing collaborative learning activities in the classroom (Barak \& Shakhman, 2008). By transferring teaching from class to home, the flipped classroom model saves class time so that the instructor can supervise collaborative learning activities (Songhao, Saito, Maeda, \& Kubo, 2011).

The information and communication technologies, such as social web apps, WebQuests, and online learning environments, have paved the way to the development of the CL studies in recent years (López-Yáñez, Yáñez-Márquez, Camacho-Nieto, AldapePérez, \& Argüelles-Cruz, 2015). Social technology media such as WebQuest contribute to establishing students' engagement outside the classroom in the flipped model that can enhance collaborative student learning, especially when virtually working together in different locations, using different online technology tools (Liu, Tao, Chen, Chen, \& Liu, 2013).

Technology has provided learners with the opportunity to enjoy more collaborative learning through different online applications. Online collaborative learning has been defined as a learning process in which students work together online to explore a topic by applying what they have learned and cultivating their analytical and judging abilities in the flipped classroom's carefully prepared materials (Hwang, Lai, \& Wang, 2015). Ebadi and Rahimi (2017) indicate that the web-based contexts provide students with the opportunity to actively engage with their pre-specified assignments as a prerequisite 
for their collaborative activities in the classroom. Furthermore, online interactions help teachers check students' collaboration and their contribution to learning processes. One innovative approach to encourage active classroom participation is the flipped instruction, in which the new knowledge is mainly presented via online out-of-class videos and other related materials.

\section{Flipped classroom}

With the advancement of computer technology, the flipped classroom as a new approach to blended learning was introduced to teaching context where teachers could save some classroom time by removing the main teaching contents outside of the classroom. Bergmann and Sams (2014) point out that the flipped approach is more straightforward and will easily fit into any class type and teaching context. As an innovative approach to the teaching context, the flipped classroom criticizes the traditional forms of teaching in which teachers were considered the only source of knowledge, and no significant roles were designated to learners (Freeman et al., 2014). Guo (2019) believes that a flipped classroom is a pedagogical model that encourages students' active participation, promotes support from teachers and peers to handle homework, and allows more free time in class. The flipped classroom emphasizes students' preparation before class time. It involves blended learning-a combination of face-to-face in-class learning and distance learning by using ready-made educational videos from various websites (Hung, 2015). The flipped instruction seems to allow teachers to remove the primary and time-consuming part of teaching to allow them more time to focus on studentcentered and active learning.

A number of flipped classroom advantages have been reported in the literature. The flipped classroom's primary potential involves flexibility that provides learners with the opportunity to learn freely at their own pace anytime by reviewing the ready-made contents pre-class (Karabulut-Ilgu et al., 2018). In the Iranian EFL background, Abaeian and Samadi (2016) studied the flipped classroom's impact on the understanding of Iranian EFL learners' L2 reading comprehension with different levels of proficiency. In this respect, the research was conducted among 100 EFL female learners. The results revealed that the experimental group outperformed the control group substantially. The flipped model was more effective for the intermediate students compared to the upper intermediate ones.

Abeysekera and Dawson (2015) indicate that since the flipped classroom approach involves both out-of-class and in-class activities, it tailors individualized instruction to diverse learners' proficiency, which in turn manages the learning' cognitive load. In a flipped classroom, students work collaboratively on the materials already prepared and delivered, which requires them to learn key concepts, and processes using the information offered in the flipped instruction. Different students of various proficiency levels should apply what they have learned in the flipped class through meaning negotiation. During the process of collaborative learning, students need to divide the work and cooperate to complete the learning tasks through both out-of-class and in-class activities to reduce the cognitive load (Tucker, 2012). The out-of-class activities are sometimes delivered online through the medium of WebQuest to provide easy access to readymade materials within a well-established framework. 


\section{WebQuest}

Through a flipped classroom, some online digital contents are presented to the learners before teaching starts through WebQuests (Ebadi \& Rahimi, 2017). WebQuests make a linkage between the Internet and the classroom (McManus, 2000), which provides learners with diverse knowledge and information sources. In a WebQuest program, the objectives of the learning and the prerequisite information are provided as the first step. Then, the tasks of students will be explained as a way of increasing communication and exchanging ideas among the learners (Lin \& Atkin, 2014; Ricalde, Hernández, \& Luna, 2013). As a result of this pre-class presentation, the students get familiar with the topic and become more active in face-to-face classes. As an alternative learning tool, WebQuest allows learners to understand the language by reviewing the available sources of the web (Laborda, 2009) and makes them more autonomous in language learning (Lou, 2010; Warda, 2016). WebQuests' underlying theoretical framework is constructivism, which conceptualizes learning as a process that actively constructs knowledge (Duffy \& Cunningham, 1996). From this perspective, WebQuests contribute to students' cooperative learning, where group members are individually engaged in creating knowledge to scaffold the in-class instruction (Irzawati \& Asiah, 2013; Tuan, 2011).

A number of studies supported WebQuests' positive effect on the learning experience (Aydin, 2015; Gülbahar, Madran, \& Kalelioglu, 2010; Hung, 2015). Abbitt and Ophus (2008) reported the positive attitudes of non-adult learners towards the WebQuest approach. The reasons involved the motivating feature of the method, learners' autonomy in choosing the learning time and doing the exercises, easy access to the learning sources, and the possibility of interaction with other learners in the classroom.

A WebQuest task makes learners think critically and motivates them to interpret the learning material. Students in a WebQuest-based flipped classroom learn the content before class in their own private time and space, making higher-order thinking processes possible because they activated related background knowledge to the content. The cognitive load theory (Sweller, 2005) supports this claim; it believes that cognitive capacity in working memory is limited. Learning will be hampered if a learning task requires too much capacity (De Jong, 2010).

This task encourages high-level thinking processing and promotes problemsolving skills, enhancing reading comprehension (Barnawi, 2009). Puthikanon (2009) reported that students actively analyzed, synthesized, and reflected on information about the topic while using WebQuest. These mental skills, which are at the core of critical thinking (Facione, 2011), are also employed in reading comprehension (Grabe, 1991). Ikpeze and Boyd (2007) claimed that WebQuests provide various content activities that facilitate critical thinking skills by evaluating web resources. This justifies the selection of WebQuest to improve EFL learners' inferential reading comprehension. Alshumaimeri and Almasri (2012) explored the impacts of using WebQuest on Saudi male EFL students' reading comprehension performance. They found that using WebQuest improved the experimental group's post-test in reading comprehension performance. Tsai (2006) used WebQuests to enhance the normal reading instruction practice in EFL reading courses of Taiwanese EFL university students. He found that students engaging with WebQuests significantly outperformed those in the control group in their vocabulary learning and story reading comprehension. 


\section{Methodology \\ Design}

This study used a mixed-methods design (Riazi \& Candlin, 2014; Tashakkori \& Teddlie, 2003) to address the research questions. The results related to WebQuest-based flipped classroom effects on EFL learners' inferential reading skills were analyzed quantitatively, and participants' attitudes and perceptions towards their experience in the WebQuestbased flipped classroom were analyzed qualitatively using thematic analysis to help explain, substantiate, and clarify the quantitative findings.

\section{Participants}

A randomized sampling method (Dörnyei, 2007) was used for selecting the participants in this study. Two classes at a language institute in Iran were selected randomly and divided into experimental and control groups. Each group's participants consisted of 20 adult EFL learners who have been studying English for 2 years in the age range of 18-24 with Persian (65\%) and Kurdish (35\%) first languages. They attended an IELTS preparation course to improve their proficiency in all four English learning skills, namely reading, writing, speaking, and listening, to participate in the IELTS actual test.

The DIALANG test, a diagnostic language assessment system for learners, available at https://dialangweb.lancaster.ac.uk/, was used to measure the participants' English proficiency levels. It is an online test of proficiency in European languages that evaluates language skills, reports scores, and provides diagnostic feedback to the participants based on their performance in the test according to the standards of the Common European Framework of Reference for Languages (CEFR) (Huhta et al., 2002). Since this study mainly dealt with the reading comprehension skill, the reading section results of the DIALANG test, which are reported in six levels of A1 to C2, were taken into consideration. The participants of this study were reported to be at B1 level in their reading comprehension proficiency. Since the learners had no previous acquaintance with the WebQuest-based flipped classroom approach, guidelines were provided to them by the instructor. To ensure learners' anonymity and protect their identities, the experimental group participants were named E1, E2, ..., and E20.

\section{Materials and instruments}

As the participants attended an IELTS preparation course to develop their reading comprehension and other language skills, their inferential reading skills were usually represented by their answers to the reading inferential items in the academic IELTS reading test. Alderson (2000) states that drawing logical inferences is an important task type in the academic IELTS reading test used to evaluate candidates' reading comprehension skills. Ghanizadeh, Pour, and Hosseini (2017) suggest that students exhibiting a higher level of inference-making can logically have better achievements in the reading comprehension section of the IELTS test.

Inferential reading skill items, including inferences and rhetorical purpose as higher-level reading comprehension items (Schedl, Gordon, Carey, \& Tang, 1996), were selected as target questions in this study. These item types involve different reading strategies and skills, making them cognitively demanding for learners (Jang, 
2009). Inferential questions referred to those items that need a reading passage to be appraised as a whole, such as questions requiring the test takers to use their logic to understand the points not directly mentioned in the text. For these tasks, the test takers cannot find any direct relationship between the text and the proposed alternatives in the questions, but they require a pragmatic or interpretative perception of the text. For the IELTS academic inferential reading tasks, the participants were asked to spend about $50 \mathrm{~min}$ on questions based on each reading passage. The candidates might alternatively be involved in comprehending the implied meanings of texts, determining the way of persuading the readers by the text for behaving or thinking in a specific way, understanding different methods of writing texts according to different readers they might have, and realizing different ways of reading texts by a different audience. IELTS reading band descriptor was used to mark the inferential reading skills of the participants. The scores given to the participants ranged from 1 to 9 for each reading passage. The final IELTS inferential reading skill for the participants was calculated based on their inferential reading task scores ranging from 1 to 9 at intervals of 0.5 .

Inter-rater reliability was used to reduce any signs of bias in scoring the test. An experienced IELTS instructor was asked to reassess the pre-tests, post-tests, and delayed post-tests taken in the study to ensure the scores' consistency. The consistency of results in the two scoring processes was confirmed $(r=0.82)$.

For the reading comprehension tests in this study, IELTS reading test samples were collected from the following sources: (a) the official IELTS Practice Test (Cambridge ESOL, 2009) and (b) practice tests released by Cambridge University Press.

A semi-structured interview based on Hung's model (Hung, 2015) was conducted to investigate the participants' attitudes and viewpoints about the WebQuest-based flipped classroom in improving their inferential reading skills. The interviews were recorded, transcribed, and coded for later thematic analysis. The member checking technique (Creswell, 2007) was used to increase the credibility of the interviews' data in which the interviewer explained the questions asked in the interview so that the interviewees understand the details of each question, which contributes to the credibility of the interview results.

\section{Procedures}

The WebQuest (Table 1) developed by one of the researchers and was given to the experimental group included a presentation of the teaching resources and exercises, an explanation of the guidelines, pedagogical videos, other electronic tools, and helpful links to reliable websites about the lessons' contents. Therefore, there was an opportunity for the experimental group participants to view the materials and contents before attending the class, which provided them with more free time to cooperate with their peers in the learning process and practice their inferential reading skills. Despite the differences in the WebQuest-based flipped classroom teaching format and the traditional face-to-face classroom in which the e-learning materials and the printed format of materials were applied, respectively, the selected reading passages were identical in both groups. The only difference between the experimental and control groups was the lack of access to the control group's online materials. 
Table 1 A brief description of the WebQuest designed for the study

\begin{tabular}{ll}
\hline Section & Activity \\
\hline Introduction & $\begin{array}{l}\text { The learners were familiarized with inferential reading skills (i.e., combine ideas, draw } \\
\text { conclusions, interpret and infer information) and IELTS academic reading tasks. }\end{array}$ \\
Task & $\begin{array}{l}\text { The required information about the learners' expected performance in doing the tasks } \\
\text { regarding the inferential reading skills was explained. }\end{array}$ \\
Process & $\begin{array}{l}\text { Necessary guidelines for thinking critically about the tasks and completing the IELTS academic } \\
\text { reading tasks were provided. The required steps for collaboration and sharing information in } \\
\text { doing the tasks were discussed. }\end{array}$ \\
Evaluation & $\begin{array}{l}\text { The inferential reading skills were assessed by IELTS reading band descriptors. The required } \\
\text { information about the assessment process was given to the learners before they began doing } \\
\text { the tasks. } \\
\text { In the end, the learners were reinforced that the WebQuest could improve their reading } \\
\text { comprehension skills in general and inferential reading skills in IELTS academic reading tasks in } \\
\text { particular. }\end{array}$
\end{tabular}

To view the WebQuest, follow this link: http://zunal.com/webquest.php?w=376052

Table 2 presents the graphical information of the procedure.

Since the learners in the experimental group were unfamiliar with the WebQuestbased flipped classroom, the first 2 weeks were devoted to technological requirements of the study and familiarizing the participants with the context. The classes were held twice weekly for about 3 months. In the flipped group, the instructor provided the participants with necessary information about WebQuests, which facilitated the engagement and collaboration among the learners before class. During class, the instructor elaborated on the introduced new points in the WebQuest about inferential reading skills. She also prepared and submitted a summary of the results and points raised in each session to the learners. After the class, the learners formed small groups at the end of each session and prepared a report on what they had learned and shared it with other groups at the class as a general overview of the materials. The traditional face-toface model of teaching reading was applied for the control group in which the printed format of instructional material was used to develop their inferential reading skills.

To assess inferential reading skill, three IELTS academic reading passages were presented to the participants as a pre-test, and then it was followed by questions that needed inference-making. The text content was the same in both groups. The instructor regularly checked the inferential reading skills of the learners and made a comparison of the results with the previous sessions to record the probable improvements in the learners' inferential reading according to the IELTS reading band descriptor. Three reading passages were given to the participants as the pre-test, all of which were derivatives of the IELTS academic reading tasks. The participants were supposed to complete the task (identifying writer's view) in $50 \mathrm{~min}$. Finally, three other reading tasks similar to the previous ones in terms of difficulty level were administered once more, this time as the post-test and $45 \mathrm{~min}$ was allocated to complete the tasks (identifying writer's view and matching headings) to see the differences regarding the learners' development in the inferential reading skills. After the post-test, a semi-structured interview was conducted to investigate the attitudes and viewpoints of the participants about the WebQuest-based flipped classroom in improving their inferential reading skill. Each interview lasted around 15 min, was held in Persian to avoid misunderstanding, and translated into English for thematic analysis, which is used in qualitative studies to uncover the themes and categories hidden in the procedures and events 
Table 2 Schematic presentation of the steps taken in the procedure

\begin{tabular}{|c|c|c|c|c|c|c|c|c|}
\hline $\begin{array}{l}\text { Participants' } \\
\text { orientation } \\
\text { to } \\
\text { WebQuest }\end{array}$ & $\begin{array}{l}\text { Sharing } \\
\text { the } \\
\text { WebQuest } \\
\text { with EG } \\
\text { Before } \\
\text { class }\end{array}$ & $\begin{array}{l}\text { Online } \\
\text { presentation } \\
\text { of WebQuest } \\
\text { materials for } \\
\text { EG } \\
\text { During class }\end{array}$ & $\begin{array}{l}\text { Formation } \\
\text { of small } \\
\text { group } \\
\text { discussions } \\
\text { After class }\end{array}$ & $\begin{array}{l}\text { Presentation } \\
\text { of print-out } \\
\text { materials of } \\
\text { WebQuest } \\
\text { for CG }\end{array}$ & $\begin{array}{l}\text { Pre-test } \\
\text { of IELTS } \\
\text { reading } \\
\text { passages }\end{array}$ & $\begin{array}{l}\text { Post-test } \\
\text { of IELTS } \\
\text { reading } \\
\text { passages }\end{array}$ & $\begin{array}{l}\text { Interviewing } \\
\text { the EG } \\
\text { participants }\end{array}$ & $\begin{array}{l}\text { Delayed } \\
\text { post-test }\end{array}$ \\
\hline
\end{tabular}

(Boyatzis, 1998). For assuring the credibility of the interviews, the transcribed versions of each interview were handed out to the interviewees to recheck their answers and make necessary changes through the member checking technique. Around a month after this step, a delayed post-test with similar features to the pre-test and post-test was administered to check the long-term effects of the WebQuest-based flipped classroom and compare those effects with the results of the face-to-face classroom in improving the learners' inferential reading skills.

\section{Data analysis}

The inferential reading skill was the dependent variable, and the WebQuest-based flipped classroom involving two forms of WebQuest-based flipped classroom and the traditional face-to-face method was the independent variable in this study. Therefore, the one-way repeated measures ANOVA was run to find the WebQuest-based flipped classroom's effect on the learners' reading comprehension skills within the experimental group, and the $T$-test was run to analyze the differences of the post-test and delayed post-test scores between the control and experimental groups.

In addition to the quantitative analysis of the data, a qualitative analysis was also conducted by analyzing the transcribed interviews based on open thematic coding. Accordingly, the interrelationships among the core variables of the study were explored, coded, and categorized based on common themes through a bottom-up approach.

\section{Results}

\section{Quantitative analysis}

As the first step, the pre-test results' descriptive statistics were evaluated to see the potential differences in the learners' inferential reading skills between the experimental and control groups before running the WebQuest. The results are presented in Table 3.

The mean scores in both groups for the pre-test were the same, and the standard deviations in the two groups were close. Thus, both groups' basic inferential skills were identical, and almost no differences could be found. To check the normality of the data, a Kolmogorov-Smirnov test was run, the results of which are shown below.

Table 4 shows that the sig. (two-tailed) in this test for the pre-test, post-test, and delayed post-test equaled 1.3, 1.7, and 1.1, respectively, and all three were greater than 0.05 , which shows the normality of data in all three tests with no outliers.

Table 3 Descriptive statistics of the pre-test scores in experimental and control groups

\begin{tabular}{lllll}
\hline & Groups & Mean & Std. deviation & Number \\
\hline Inferential reading skills & Ex & 5.5 & 0.435 & 20 \\
& Co & 5.5 & 0.442 & 20 \\
\hline
\end{tabular}


Table 4 The one-sample Kolmogorov-Smirnov test for normality of data

\begin{tabular}{llll}
\hline $\boldsymbol{E}$ & Pre & Post & De. po \\
\hline$N=40$ & & & \\
Normal parameters & & & \\
$\quad$ Mean & 0.0237 & 0.0289 & 0.5124 \\
$\quad$ SD & 0.4211 & 0.4056 & 0.1025 \\
Most extreme differences & & & \\
$\quad$ Absolute & 0.151 & 0.211 & 0.012 \\
$\quad$ Positive & 0.241 & 0.500 & 0.357 \\
$\quad$ Negative & -0.055 & 0.044 & -0.085 \\
Kolmogorov-Smirnov Z test & 0.476 & 0.071 & 0.014 \\
Asymp. sig. (2-tailed) & 1.328 & 1.758 & 1.126 \\
\hline
\end{tabular}

In the next step, to examine the effects of the WebQuest-based flipped classroom on the learners' scores in the experimental group and compare it to the learners' scores in the control group, a $T$-test was run.

Table 5 shows the result of the independent sample test for the post-test and delayed post-test. It can be inferred that the sig. (two-tailed) value ( $P$-value) of the scores was .001. Because this value is smaller than $P>0.05$ for the experimental group, a significant relationship was found between the WebQuest-based flipped classroom and the learners' post-test and delayed post-test scores in the experimental group. As the next step, the adjusted mean differences of the post-test scores and delayed post-tests in the control and experimental groups were evaluated. We used the adjusted mean to correct statistical averages to compensate for data imbalances and significant variances.

Table 6 affirms that the adjusted means of both post-test and delayed post-test scores on the inferential reading skills were significantly higher in the experimental group compared to those means in the control group. The next step was to determine the detailed differences in the extent of effects of the method applied in the study on the post-test and delayed post-test scores in the experimental group and compare them to the control group results.

Table 7 shows that the post-test and delayed post-test scores in the experimental group were higher than the same scores in the control group, which did not undergo the WebQuest-based flipped classroom method.

Finally, to analyze the WebQuest-based flipped classroom method's effects, a pairsampled $T$-test was conducted to compare the inferential reading ability in the participants within the experimental group through a period evaluated by the post-test and delayed post-test. This analysis can reveal more precise information about the possible effects of the independent variable (WebQuest-based flipped classroom method) on the dependent variable (reading proficiency) after collecting post-test and delayed post-test results. The following table provides data in that regard.

Table $\mathbf{5}$ Independent sample test between the experiment and the control groups

\begin{tabular}{|c|c|c|c|c|c|c|}
\hline \multicolumn{7}{|c|}{$T$-test for equality of means } \\
\hline \multirow[t]{2}{*}{$F$} & \multirow[t]{2}{*}{ Sig. } & \multirow[t]{2}{*}{$t$} & \multirow[t]{2}{*}{ df } & \multirow{2}{*}{$\begin{array}{l}\text { Sig. } \\
(2- \\
\text { tailed) }\end{array}$} & \multicolumn{2}{|c|}{$95 \%$ confidence interval of the difference } \\
\hline & & & & & Lower & Upper \\
\hline .235 & .751 & 1.412 & 752 & .001 & .13523 & .03283 \\
\hline
\end{tabular}


Table 6 Unadjusted mean differences of the post-tests and delayed post-tests for both groups

\begin{tabular}{|c|c|c|c|c|c|}
\hline \multirow[t]{2}{*}{ Dependent variable } & \multirow[t]{2}{*}{ Group } & \multirow[t]{2}{*}{ Mean } & \multirow{2}{*}{$\begin{array}{l}\text { Std. } \\
\text { error }\end{array}$} & \multicolumn{2}{|c|}{$95 \%$ confidence interval of the difference } \\
\hline & & & & Lower & Upper \\
\hline \multirow[t]{2}{*}{ Inferential reading skill (post-test) } & EX & 7.217 & 0.232 & 6.320 & 7.519 \\
\hline & $\mathrm{CO}$ & 6.332 & 0.119 & 5.217 & 5.993 \\
\hline \multirow[t]{2}{*}{ Inferential reading skill (delayed post-test) } & EX & 8.231 & 0.250 & 7.782 & 7.953 \\
\hline & $\mathrm{CO}$ & 6.121 & 0.112 & 4.821 & 5.213 \\
\hline
\end{tabular}

As it can be inferred from Table 8, there was a significant difference in reading proficiency between at least two-time intervals determined by the post-test and delayed post-test taken in the experimental group. Table 8 indicates that the delayed post-test scores were on average above 7 points higher than the scores in the post-test $(M=7.83$, S.D =4.623). Since the $P$-value achieved in this test equals .000 , which is less than .05 $(t=1.719, P=.000<.05)$, the effect of the method used in the study on the subjects is supported, it means that the WebQuest-based flipped classroom method significantly improved the learners' reading comprehension skills, which is reflected in their scores after each post-test and delayed post-test.

\section{Qualitative analysis}

The following sections present the themes that emerged from the analysis of the semistructured interviews of 10 volunteers from the experimental group. The participants' attitudes and perceptions towards the use and effect of the WebQuest-based flipped classroom on inferential reading skills are presented below.

\section{Helpful nature of videos and other learning materials}

The analysis of the interviews highlighted the positive attitudes of the participants in general. The learners generally asserted that the WebQuest-based flipped classroom had positive effects on their inferential reading skills and preferred the method to other traditional approaches for reading comprehension. E20, for example, reported that:

All the required information for the reading comprehension task was provided to me through the instructional materials that I read every session before going to class, and they trained me how to read the texts inferentially, which became a habit of understanding the hidden meaning in the texts.

The learners also reported that using WebQuest materials was easy and provided the necessary information about how to read inferentially. E9 stated that:

Table 7 Pairwise comparisons of the results in both groups based on the post-test and delayed post-test scores

\begin{tabular}{llllll}
\hline Dependent variable & Group (I) & Group (J) & Mean difference (I-J) & Standard error & Sig. \\
\hline Inferential reading skills (post-test) & Experimental & Control & 4.451 & 0.48575 & 0.003 \\
Inferential reading skills (delayed) & Experimental & Control & 5.735 & 0.96512 & 0.001 \\
\hline
\end{tabular}


Table 8 Pair-sampled T-test for the post-test and delayed post-test

\begin{tabular}{|c|c|c|c|c|c|c|c|c|}
\hline & \multicolumn{5}{|c|}{ Paired differences } & \multirow[t]{3}{*}{$t$} & \multirow[t]{3}{*}{ df } & \multirow{3}{*}{$\begin{array}{l}\text { Sig. } \\
(2-t)\end{array}$} \\
\hline & \multirow[t]{2}{*}{ Mean } & \multirow{2}{*}{$\begin{array}{l}\text { St. } \\
\text { deviation }\end{array}$} & \multirow{2}{*}{$\begin{array}{l}\text { St- } \\
\text { error } \\
\text { mean }\end{array}$} & \multicolumn{2}{|c|}{$95 \%$ confidence interval of the difference } & & & \\
\hline & & & & Lower & Upper & & & \\
\hline Post-Del & 7.83 & 4.6237195 & .27481 & .33845 & .41992 & 1.719 & 4 & .000 \\
\hline
\end{tabular}

It was easy to use the materials since they enjoyed a logical organization which made them easy to understand and use. The method firstly introduced inferential reading and provided related practices and then guided me to improve my skill.

\section{Autonomy in learning style}

The autonomy given to the learners by WebQuest in choosing what and how to watch the videos and check other online materials was appreciated by some participants. They could freely choose the informative videos to watch several times and alternatively skip the less helpful ones. E1, for instance, said that:

I watched some of the videos repeatedly since they involved information about the areas that I had difficulty. Some others, on the other hand, were easy to understand, and I did not need to watch more than once.

\section{Free access to contents without the limitation of time and space}

Some participants held positive attitudes towards the WebQuest-based flipped classroom since it gave them as much time as they needed for viewing and reviewing the videos and studying the materials. It was possible to watch the videos repeatedly if they missed the class entirely or partially. E18 mentioned:

One session, I was sick and missed the class, but I could learn all the contents of that session through the WebQuest-based flipped classroom after watching the video related to that session. I needed to watch that video several times to ensure that I had mastered the technique.

\section{Participation in class discussions}

The in-class discussions were reported to have a significant role in enhancing the learners' perception. The EFL learners indicated that these discussions about the videos and other related materials led them to learn various points from their classmates. E2 stated that:

When discussing the contents with other students, I asked about the difficult points, which helped me in several cases to solve my problems through class discussions.

The WebQuest-based flipped classroom could keep the learners motivated in doing the reading comprehension tasks and give them positive feelings to cooperate in classroom activities. E7 reported that: 
Since I could watch the videos and study the materials related to the contents before class time, I felt confident to take part in the class discussions, which made me interested in both the class context and the topic discussed.

\section{Discussion}

Reading comprehension encompasses analyzing and interpreting a text and reading between the lines, which entails higher-order thinking skills. Ku (2009) points out that students must go beyond absorbing knowledge and learn to heighten skills to interpret information in a text. The inferential reading ability is a cognitively demanding skill involving learners' different mental activities while engaged with the reading materials (Goudvis \& Harvey, 2000). Therefore, according to Teo (2012), EFL learners' inferential reading skills reflect their understanding of the overall picture in reading materials and develop their critical thinking skills. Collins (1993) indicates that learners need to be critical thinkers to understand the text and facilitate complex interaction. In the same vein, Waters (2006) stated that critical thinking provides learners with instruments that help them go beyond the text's information. Ebadi and Rahimi (2017) point out that WebQuests' use seems to develop higher-order thinking skills, including critical thinking skills, as the learners seem to have more time and space to reflect upon and find solutions to the learning problems before attending the class. These higher-order thinking skills are presumably a tool for developing inferential reading comprehension skills that require reading between the lines. This research's findings corroborate the results of Aydin (2015), Ebadi and Rahimi (2017), Sen and Neufeld (2006), and Vidoni and Maddux (2002), which showed that the WebQuest-based method improved the critical thinking among the learners. Zheng, Perez, Williamson, and Flygare (2008) found the WebQuest-based flipped classroom a useful learning method that involves critical thinking. Ebadi and Rahimi (2017) asserted that the WebQuest-based flipped classroom could enhance both the learner's responsibility and motivation levels to a greater extent than the traditional teaching language method. It is assumed that critical thinking results from the in-depth perception of the learning contents, which is achieved through the specific instruction of the WebQuest requiring critical thinking and other thinking skills. The results highlighted the fact that learning essential skills of thinking might lead to improving inferential skills. An inferential understanding involves integrating the background knowledge with the linguistic knowledge to make the learners read between the lines of a text and connect the dots between directly and indirectly mentioned information. This cognitive processing ability needs to be taught to learners as they are not naturally endowed with this ability. Inferential reading comprehension becomes more difficult and complicated when it comes to a foreign language learning context because EFL learners have to bear upon a form of sociocultural understanding to infer the hidden concepts of the texts.

Weinstein (2000) believes that critical thinking is improved by providing reliable information relating to the contexts. The WebQuest-based flipped classroom is an opportunity for practicing and developing critical thinking skills, which results in improving inferential reading skills and organizing and saving learners' time and energy by focusing only on related materials available online. This finding is in line with Bagheri and Ghanizadeh (2016) that reported a positive correlation between critical thinking and inferential reading comprehension among Iranian EFL students. This study's results 
indicate that the students in the flipped classroom interacted more deeply with the reading passages. This is in line with Kim, Park, Jang, and Nam (2017) studying the flipped classroom approach's cognitive effects in a content-based instructional context. The results revealed that the flipped classroom students produced more cognitive comments involving deeper information processing and higher-order reasoning skills, which highlighted the fact that flipped classrooms can effectively promote higher-order thinking processes.

Dodge (2001) states that the WebQuest-based flipped classroom's inquiry-oriented practices develop learners' critical thinking. Gülbahar et al. (2010) argue that WebQuest practices involve information analysis, synthesis, problem-solving, and judgment, leading to reinforcing the critical thinking ability in general and inferential reading skills in particular as evidenced in this study. The enhancement of the critical thinking and inferential reading skills and perception of the learners may take root from the autonomous format of WebQuest, which can also maintain the learners' interest in the learning process (Weinstein, 2000). The results of this study highlighted the impacts of the instructional method of the WebQuest-based flipped classroom, which provided learners with enough time to understand and review the learning materials several times. The learners had the opportunity to be engaged in collaborative learning. The flipped classroom model in this study saved class time to engage in collaborative learning activities using their already processed information available in the WebQuest. This is in line with Fulton (2012) who found students in flipped classroom study focused on self-directed learning ability and working at their own pace, making students more comfortable working together and collaboratively solving the problem (Tucker, 2012).

The next important feature of the WebQuest-based method can be the possibility of having online access to the instructor's sources regardless of time and space, which results in higher motivation to learn and save time. Thus, this method could be considered learner-centered, encouraging learners' independence and autonomy rather than depending on a teacher.

The interviews with the participants affirmed a generally positive attitude towards the WebQuest-based flipped classroom as an effective method in developing the learners' inferential reading skills. The participants of this study highlighted some challenges in using WebQuest. Some of the points raised by the learners as the problematic aspects of the method, however, involved the amount of time they needed for out-of-class activities, the unpredictability of the context, and popping up problems related to the Internet access or filtering issues which corroborated the findings of Yang, Yin, and Wang (2018).

The findings pointed out the positive impact of the WebQuest-based approach on the learners' inferential skills, which could be attributed to familiarity with the social media, which in turn enhances the level of interaction among the learners and motivates them to use social media affordances as learning tools. This finding corroborates Puthikanon's (2009) study, which pointed out that students analyze and reflect on information related to the topic of WebQuest.

Regarding the pedagogical implication of this approach in the classroom, the flipped instruction often starts with pre-class content delivered via WebQuests through which teachers hope to transmit knowledge to students. The flipped classrooms enable students to benefit more from classroom time and have more time for interaction, active 
collaborative learning, and assessment (Fulton, 2012). In this regard, the results of the present study are in line with those of Hung (2015), who reported that the flipped instructional model develops the academic performance of students in general in English classes. A flipped classroom can offer teachers many benefits. It frees them from the conventional ways of teaching and introduces the modern teaching methods effectively. In addition, as Enfield (2013) pointed out, this model "was successful in helping students learn the content, and increased self-efficacy in their ability to learn independently" (p. 14).

However, there is a challenge for WebQuest contents to be effective as students might not be interested in reading the pre-specified content or might have difficulty in understanding it (Gaughan, 2014; Zainuddin \& Attaran, 2016). This study highlighted the fact that learners are likely to develop their inferential reading skills if the instruction to the WebQuest-based approach is appropriately tailored to their needs. The videos that the learners were provided with included the related topics to each session's training content, which motivated learners to engage with the contents more efficiently in the classroom. As the flipped classroom is active learning that makes the learners more interactive in learning activities, the videos made it possible for them to collaborate to discuss the lessons after watching them outside the class (Milman, 2012). This helps them construct their knowledge collaboratively based on previous knowledge and experience gained through WebQuest.

DeCaro and Rittle-Johnson (2012) suggested that for direct instruction to be effective, students' background knowledge should be activated for learning. Scheiter et al. (2009) reported that students with higher levels of prior knowledge utilize deeper processing strategies because the prior knowledge guides their information selection and thus reduces their cognitive load during learning. The participants in this study expanded their knowledge by activating the schemas before the class discussion, which improved their critical thinking and inferential reading skills. Teachers are recommended to tailor the videos in terms of the length and structure to make them more stimulating for the learners and design some out-of-class activities to activate learners' background knowledge concerning the flipped content presented via WebQuests. On the other hand, the in-class discussions after watching the videos might help solve some of the learners' problems while watching them. Hence, teachers need to pay special attention to the inclass collaboration and discussions to enhance the learners' engagement with the topics.

One of the study's limitations was the participants' lack of familiarity with flipped learning as they used to learn through traditional language learning methods. Although they were trained about using the WebQuest, some of them quitted the study because of the complexities involved in using the WebQuest and were replaced by other learners in the control group. One generic limitation of most flipped studies, which was highlighted by Guo (2019), is a gap between the flipped classroom's theoretical advantages and its practical effectiveness as there is no way for teachers to ensure that learners understood pre-class WebQuest contents, which are a prerequisite for implementing the flipped classroom.

The participants of this study were a group of intermediate learners attending an IELTS course. A similar study could be conducted on EFL elementary levels of language proficiency. Furthermore, the teachers' attitudes towards the WebQuest-based 
flipped classroom and evaluating their ideas on the approach could be explored in future studies to develop a comprehensive pedagogical curriculum based on the WebQuest-based flipped classroom for the EFL learners.

\section{Acknowledgements}

Not applicable.

\section{Authors' contributions}

Both authors equally contributed to the development of the study. The author(s) read and approved the final manuscript.

\section{Funding}

This research project was not funded by any organization.

\section{Availability of data and materials}

Not applicable.

\section{Declarations}

\section{Competing interests}

The authors declare that they have no competing interests.

Received: 27 October 2020 Accepted: 4 April 2021

Published online: 07 May 2021

\section{References}

Abaeian, H., \& Samadi, L. (2016). The effect of flipped classroom on Iranian EFL learners' L2 reading comprehension: Focusing on different proficiency levels. Journal of Applied Linguistics and Language Research, 3(6), 295-304.

Abbitt, J., \& Ophus, J. (2008). What we know about the impacts of WebQuests: A review of research. AACE Journal, 16(4), 441456.

Abeysekera, L., \& Dawson, P. (2015). Motivation and cognitive load in the flipped classroom: Definition, rationale, and a call for research. Higher Education Research and Development, 34(1), 1-14. https://doi.org/10.1080/07294360.2014.934336.

Alderson, J. C. (2000). Technology in testing: The present and the future. System, 28(4), 593-603. https://doi.org/10.1016/S034 6-251X(00)00040-3.

Alshumaimeri, Y. A., \& Almasri, M. M. (2012). The effects of using WebQuests on reading comprehension performance of Saudi EFL students. Turkish Online Journal of Educational Technology-TOJET, 11(4), 295-306 Retrieved from http://www. tojet.net/articles/v11i4/11429.pdf.

Arsanjani, M., \& Faghih, E. (2015). The impact of the Webquest instruction system on Iranian intermediate EFL learners' writing performance and perception. International Journal of Instructional Technology and Distance Learning, 12(2), 37-47 Retrieved from http://itdl.org/Journal/Feb_15/Feb15.pdf.

Aydin, S. (2015). WebQuests as language-learning tools. Computer Assisted Language Learning, 29(4), 765-778.

Baepler, P., Walker, J. D., \& Driessen, M. (2014). It's not about seat time: Blending, flipping, and efficiency in active learning classrooms. Computers \& Education, 78, 227-236. https://doi.org/10.1016/j.compedu.2014.06.006.

Bagheri, F., \& Ghanizadeh, A. (2016). Critical thinking and gender differences in academic self-regulation in higher education. Journal of Applied Linguistics and Language Research, 3(3), 133-145.

Barak, M., \& Shakhman, L. (2008). Fostering higher-order thinking in science class: Teachers' reflections. Teachers and Teaching: Theory and Practice, 14(3), 191-208.

Barnawi, O. Z. (2009). The internet and EFL college instruction: A small-scale study of EFL college teachers' reactions. International Journal of Instructional Technology and Distance Learning, 6(6), 47-64 Retrieved from http://www.itdl.org/ Journal/Jun_09/article04.htm.

Bergmann, J., \& Sams, A. (2014). Flipped learning: Gateway to student engagement. International Society for Technology in Education.

Boucher, B., Robertson, E., Wainner, R., \& Sanders, B. (2013). "Flipping" Texas State University's physical therapist musculoskeletal curriculum: Implementation of a hybrid learning model. Journal of Physical Therapy Education, 27(3), 7277. https://doi.org/10.1097/00001416-201307000-00010.

Boyatzis, R. (1998). Transforming qualitative information: Thematic analysis and code development. Sage Publications.

Cambridge ESOL. (2009). Official IELTS Practice Materials 1 with Audio CD . Cambridge University Press.

Collins, N. D. (1993). Teaching critical reading through literature. ERIC Digest, 4, 1-5.

Creswell, J. W. (2007). Qualitative inquiry and research design: Choosing among five traditions, (2nd ed., ). Sage.

De Jong, T. (2010). Cognitive load theory, educational research, and instructional design: Some food for thought. Instructional Science, 38(2), 105-134

DeCaro, M., \& Rittle-Johnson, B. (2012). Exploring mathematics problems prepares children to learn from instruction. Journal of Experimental Child Psychology, 113(4), 552-568. https://doi.org/10.1016/j.jecp.2012.06.009.

Dodge, B. (1995). WebQuests: A technique for internet-based learning. Distance Educator, 1(2), 10-13.

Dodge, B. (2001). Focus: Five rules for writing a great WebQuest. Learning and Leading with Technology, 28(8), 6-9.

Dörnyei, Z. (2007). Research methods in applied linguistics. Oxford University Press.

Duffy, T., \& Cunningham, D. (1996). Constructivism: Implications for the design and delivery of instruction. MacMillan.

Ebadi, S., \& Rahimi, M. (2017). Exploring the impact of online peer-editing using Google Docs on EFL learners' academic writing skills: A mixed methods study. Computer Assisted Lanquage Learning, 30(8), 787-815. https://doi.org/10.1080/ 09588221.2017 .1363056 
Enfield, J. (2013). Looking at the impact of the flipped classroom model of instruction on undergraduate multimedia students at CSUN. TechTrends, 57(6), 14-27.

Facione, P. A. (2011). Critical thinking: What it is and why it counts. California Academic Press.

Freeman, S., Eddy, S. L., McDonough, M., Smith, M. K., Okoroafor, N., Jordt, H., \& Wenderoth, M. P. (2014). Active learning increases student performance in science, engineering, and mathematics. Proceedings of the National Academy of Sciences, 111(23), 8410-8415. http://dx.doi.org/10.1073/pnas.1319030111.

Fulton, K. (2012). Upside down and inside out: Flip your classroom to improve student learning. Learning and Leading with Technology, 38(9), 12-17.

Gaughan, J. E. (2014). The flipped classroom in world history. History Teacher, 47, 221-244.

Ghanizadeh, A., Pour, A. V., \& Hosseini, A. (2017). IELTS academic reading achievement: The contribution of inference-making and evaluation of arguments. European Journal of English Language Teaching, 2(2), 1-21.

Goodwin, B., \& Miller, K. (2013). Evidence on flipped classrooms is still coming. Educational Leadership, 70(6), 78-80.

Goudvis, A., \& Harvey, S. (2000). Strategies that work: Teaching comprehension to enhance understanding. Stenhouse.

Grabe, W. (1991). Current developments in second language reading. TESOL Quarterly, 25(3), 375-396. https://doi.org/10.23 07/3586977.

Graesser, A. C., Singer, M., \& Trabasso, T. (1994). Constructing inferences during narrative text comprehension. Psychological Review, 101(3), 371-395. https://doi.org/10.1037/0033-295X.101.3.371.

Gülbahar, Y., Madran, R. O., \& Kalelioglu, F. (2010). Development and evaluation of an interactive WebQuest environment: Web Macerasi. Educational Technology \& Society, 13(3), 139-150.

Guo, J. J. (2019). The use of an extended flipped classroom model in improving students' learning in an undergraduate course. Journal of Computing in Higher Education, 31, 2,362-2,390.

Hamouda, A. M. S., \& Tarlochan, F. (2015). Engaging engineering students in active learning and critical thinking through class debates. Procedia - Social and Behavioral Sciences, 191, 990-995. https://doi.org/10.1016/.jsbspro.2015.04.379.

Howitt, C., \& Pegrum, M. (2015). Implementing a flipped classroom approach in postgraduate education: An unexpected journey into pedagogical redesign. Australasian Journal of Educational Technology, 31, 458-469.

Huhta, A., Luoma, S., Oscarson, M., Sajavaara, K., Takala, S., \& Teasdale, A. (2002). DIALANG: A diagnostic language assessment system for learners. In J. C. Alderson (Ed.), Common European framework of reference for languages: Learning, teaching, assessment. Case studies, (pp. 130-145). Council of Europe.

Hung, H. T. (2015). Flipping the classroom for English language learners to foster active learning. Computer Assisted Language Learning, 28(1), 81-96. https://doi.org/10.1080/09588221.2014.967701.

Hwang, G. J., Lai, C. L., \& Wang, S. Y. (2015). Seamless flipped learning: A mobile technology-enhanced flipped classroom with effective learning strategies. Journal of Computers in Education, 2(4), 449-473.

Ikpeze, C., \& Boyd, F. (2007). Web-based inquiry learning: Facilitating thoughtful literacy with WebQuests. The Reading Teacher, 60(7), 644-654. https://doi.org/10.1598/RT.60.7.5.

Irzawati, I., \& Asiah, N. (2013). Using WebQuest in learning grammar: Students' perceptions in higher education. Advances in Language and Literary Studies, 4(1), 13-19. Retrieved from http://www.journals.aiac.org.au/index.php/alls/article/view/62/ 59. https://doi.org/10.7575/aiac.alls.v.4n.1p.13.

Jang, E. E. (2009). Demystifying a Q-matrix for making diagnostic inferences about L2 reading skills. Language Assessment Quarterly, 6(3), 210-238. https://doi.org/10.1080/15434300903071817.

Karabulut-llgu, A., Jaramillo Cherrez, N., \& Jahren, C. T. (2018). A systematic review of research on the flipped learning method in engineering education. British Journal of Educational Technology, 49(3), 398-411. https://doi.org/10.1111/bjet.12548.

Kendeou, P., van den Broek, P., Helder, A., \& Karlsson, J. (2014). A cognitive view of reading comprehension: Implications for reading difficulties. Learning Disabilities Research \& Practice, 29(1), 10-16. https://doi.org/10.1111/ldrp.12025.

Kim, J., Park, H., Jang, M., \& Nam, H. (2017). Exploring flipped classroom effects on second language learners' cognitive processing. Foreign Language Annals, 50(2), 260-284.

Kintsch, W. (2012). Psychological models of reading comprehension and their implications for assessment. In J. P. Sabatini, E. R. Albro, \& T. O'Reilly (Eds.), Measuring up: Advances in how we assess reading ability. Rowman \& Littlefield Education.

Kirmizi, F. (2010). Relationship between reading comprehension strategy use and daily free reading time. Procedia Social and Behavioral Sciences, 2(2), 4752-4756. https://doi.org/10.1016/j.sbspro.2010.03.763.

Ku, K. Y. (2009). Assessing students' critical thinking performance: Urging for measurements using multi-response format. Thinking Skills and Creativity, 4(1), 70-76. https://doi.org/10.1016/j.tsc.2009.02.001.

Laborda, J. G. (2009). Using webquests for oral communication in English as a foreign language for Tourism Studies. Educational Technology \& Society, 12(1), 258-270.

Lee, S.-M. (2014). The relationships between higher order thinking skills, cognitive density, and social presence in online learning. Internet and Higher Education, 21, 41-52. https://doi.org/10.1016/j.iheduc.2013.12.002.

Lin, C. A., \& Atkin, D. J. (Eds.) (2014). Communication technology and social change: Theory and implications. Routledge. https:// doi.org/10.4324/9781410615411.

Liu, C. C., Tao, S. Y., Chen, W. H., Chen, S. Y., \& Liu, B. J. (2013). The effects of a creative commons approach on collaborative learning. Behaviour \& Information Technology, 32(1), 37-51.

López-Yáñez, I., Yáñez-Márquez, C., Camacho-Nieto, O., Aldape-Pérez, M., \& Argüelles-Cruz, A. J. (2015). Collaborative learning in postgraduate level courses. Computers in Human Behavior, 51, 938-944. https://doi.org/10.1016/j.chb.2014.11.055.

Lou, M. (2010). Web-quest [An experimental study on web-quest in promoting non-English majors' learner autonomy]. Journal of Heilongjiang College of Education, 29(4), 148-150.

Mcclelland, C. J. (2013). Flipping a large-enrollment fluid mechanics course-Is it effective? In Paper presented at proceedings of the 120th ASEE annual conference and exposition, Atlanta, GA.

McKoon, G., \& Ratcliff, R. (1992). Inference during reading. Psychological Review, 99(3), 440-466. https://doi.org/10.1037/0033-295X.99.3.440.

McManus, T. F. (2000). Individualizing instruction in a web-based hypermedia learning environment: Nonlinearity, advance organizers, and self-regulated learners. Journal of Interactive Learning Research, 11(2), 219-251.

Milman, N. B. (2012). The flipped classroom strategy: What is it and how can it best be used? Distance Learning, 9(3), 85-97.

Paris, S. G., \& Hamilton, E. E. (2009). The development of children's reading comprehension. In S. E. Israel, \& G. G. Duffy (Eds.), Handbook of research on reading comprehension, (pp. 32-53). Routledge. 
Pellegrino, J., \& Hilton, M. (2012). Education for life and work: Developing transferable knowledge and skills in the 21st century. National Academies Press.

Prince, M. (2004). Does active learning work? A review of the research. Journal of Engineering Education, 93(3), 223-231. https://doi.org/10.1002/j.2168-9830.2004.tb00809.x.

Puthikanon, N. (2009) Examining critical thinking and language use through the use of WebQuests in an EFL reading class (Doctoral dissertation). Available from ProQuest Dissertations and Theses database. (UMI No. 3390298).

Riazi, A. M., \& Candlin, C. N. (2014). Mixed-methods research in language teaching and learning: Opportunities, issues and challenges. Language Teaching, 47(2), 135-173. https://doi.org/10.1017/S0261444813000505.

Ricalde, C., Hernández, T., \& Luna, J. L. (2013). Self-regulation of motivation when learning online: The importance of who, why and how. Education Technology Research Development, 59(2), 199-212. https://doi.org/10.1007/s11423-011-9193-6.

Schedl, M., Gordon, A., Carey, P. A., \& Tang, K. L. (1996). An analysis of the dimensionality of TOEFL reading comprehension items, TOEFL research reports no. 53 (). Educational Testing Service.

Scheiter, K., Gerjets, P., Vollmann, B., \& Catrambone, R. (2009). The impact of learner characteristics on information utilization strategies, cognitive load experienced, and performance in hypermedia learning. Learning and Instruction, 19(5), 387-401. https://doi.org/10.1016/j.learninstruc.2009.02.004.

Sen, A., \& Neufeld, S. (2006). In pursuit of alternatives in ELT methodology: WebQuests. The Turkish Online Journal of Educational Technology- TOJET, 5(1), 49-67.

Shea, P., Hayes, S., Smith, S. U., Vickers, J., Bidjerano, T., Pickett, A., .. Jian, S. (2012). Learning presence: Additional research on a new conceptual element within the Community of Inquiry (Col) framework. The Internet and Higher Education, 15(2), 89-95. https://doi.org/10.1016/j.iheduc.2011.08.002

Songhao, H., Saito, K., Maeda, T., \& Kubo, T. (2011). Evolution from collaborative learning to symbiotic e-learning: Creation of new e-learning environment for knowledge society. Online Submission, 8(1), 46-53.

Sweller, J. (2005). Implications of cognitive load theory for multimedia learning. In R. E. Mayer (Ed.), The Cambridge handbook of multimedia learning, (pp. 19-30). Cambridge University Press.

Tashakkori, A., \& Teddlie, C. (2003). Handbook of mixed methods in social \& behavioral research. Sage.

Teo, A. (2012). Promoting EFL students' inferential reading skills through computerized dynamic assessment. Language Learning \& Technology, 16(3), 10-20.

Tsai, S. (2006). Students' perceptions of English learning through EFL WebQuest. In Paper presented at the World Conference on Educational Multimedia, Hypermedia and Telecommunications 2006, Orlando, FL.

Tuan, L. T. (2011). Teaching reading through WebQuest. Journal of Language Teaching and Research, 2(3), 664-673.

Tucker, B. (2012). The flipped classroom. Education Next, 12(1), 82-83.

Van den Broek, P., Young, M., Tzeng, Y., \& Linderholm, T. (1999). The landscape model of reading: Inferences and the online construction of a memory representation. In S. R. Goldman, \& H. van Oostendorp (Eds.), The construction of mental representations during reading, (pp. 71-98). Lawrence Erlbaum Associates Inc.

Van Dijk, T. A., \& Kintsch, W. (1983). Strategies and discourse comprehension. Academic

Velegol, S. B., Zappe, S. E., \& Mahoney, E. (2015). The evolution of a flipped classroom: Evidence-based recommendations. Advances in Engineering Education, 4, 1-37.

Vidoni, K., \& Maddux, C. (2002). WebQuests: Can they be used to improve critical thinking skills in students? The Haworth Press, 19(1/2), 101-117.

Warda, M. H. M. A. (2016). Can collaborative learning maximize the effectiveness of web-quest used in learning educational psychology at Al Majmaa University? Journal of Research in Curriculum, Instruction and Educational Technology, 2(4), 117144.

Waters, A. (2006). Thinking and language learning. ELT Journal, 60(4), 237-319.

Weinstein, M. (2000). A framework for critical thinking. High School Magazine, 7(8), 40-43,

Yang, J., Yin, C., \& Wang, W. (2018). Flipping the classroom in teaching Chinese as a foreign language. Language Learning \& Technology, 22(1), 16-26.

Zainuddin, Z., \& Attaran, M. (2016). Malaysian students' perceptions of flipped classroom: A case study. Innovations in Education and Teaching International, 53(6), 660-670. https://doi.org/10.1080/14703297.2015.1102079.

Zheng, R., Perez, J., Williamson, J., \& Flygare, J. (2008). Web-quests as perceived by teachers: Implications for online teaching and learning. Journal of Computer Assisted Learning, 24(4), 295-304. https://doi.org/10.1111/j.1365-2729.2007.00261.x.

\section{Publisher's Note}

Springer Nature remains neutral with regard to jurisdictional claims in published maps and institutional affiliations.

\section{Submit your manuscript to a SpringerOpen ${ }^{\circ}$ journal and benefit from:}

- Convenient online submission

- Rigorous peer review

Open access: articles freely available online

- High visibility within the field

- Retaining the copyright to your article

Submit your next manuscript at $\boldsymbol{\Delta}$ springeropen.com 